\title{
ASPECTS OF FOREST MANAGEMENT IN THE MAINTAINING OF FOREST ENVIRONMENT
}

\author{
Roman JASZCZAK ${ }^{1}$, Piotr GOŁOJUCH ${ }^{1}$, \\ Sandra WAJCHMAN-ŚWITALSKA ${ }^{1}$, Mariusz MIOTKE ${ }^{2}$ \\ ${ }^{1}$ Poznan University of Life Sciences, Poland \\ ${ }^{2}$ Regional Directorate for Environmental Protection in Gdańsk, Poland
}

\section{Abstract}

Forest management is a scientific discipline designed to develop methods of maintaining forest areas and to ensure the sustainable development of forest resources in terms and conditions of multifunctional forestry. This is a branch of practical forestry which deals with inventorying and assessing the state of forests, defines economic tasks and draws up a program of nature conservation for forest districts. The paper presents legal conditions related to the concept of forest management plan, as well as issues related to the area division, planning economic indications and their role for the forest environment. Authors present a forecast of impact of a forest management plan on the forest environment and the Natura 2000 sites.

Keywords: forest management plan, objectives of forest management, legal basis

\section{INTRODUCTION}

The concept, purpose and scope of forest management has evolved over the years what was described by Jaszczak and Magnuski [18], some selected historical aspects of it were described by Miś [23]; Jaszczak [7-14]; Jaszczak and Magnuski [18]; Jaszczak et al. [16], b; Jaszczak and Wajchman [15]; Magnuski and Jaszczak [20-22]. Nowadays, forest management is a scientific

\footnotetext{
${ }^{1}$ Corresponding author: Poznan University of Life Sciences, Department of Forest Management,romanj@up.poznan.pl, tel.+48 618487664

${ }^{2}$ Regional Directorate for Environmental Protection, Chmielna st 54/57, 80-748 Gdańsk, Poland, tel.+48 586836800
} 
discipline aimed at developing methods to ensure the sustainable development of forest resources in multifunctional forestry [1, 14, 23, 26]. From a practical point of view, the aim of forest management planning is to work out projects of forest management plans in accordance with the law, sustainable forest management and social expectations on the environmental protection. In order to accomplish this goal, a number of requirements are included in the Instruction for Forest Management [2012].

The implementation of these requirements results in a forest managemnet plan [Article 6.6. of the Forest Act of 1991] or an abridged forest managemnet plan [Article 6.7. of the Forest Act of 1991]. The contents of these plans have a crucial signification not olny for forest management within detrmined areas but also for the forest enviroment. Authors are focused on the second of mentioned aspects which is the forest environment. The aim of this paper is to present and discuss on selected issues related to forest management and their relevance to the forest environment.

\section{LEGAL BASICS OF FOREST MANAGEMENT}

Forest managemnet within selected areas is regulated by legal acts. The most important and basic is the Forest Act [1991], which is complemented by detailed guidelines on the conditions and procedure for drawing up individual forest management plans, contained in the Regulation of the Minister of the Environment [2012]. However, provisions on forest management are included in a number of legal acts, e.g., the Act on Access to Information on the Environment and its Protection and on Environmental Impact Assessment [2008], the act on Environmental Protection Law [2001], the Act of Nature Conservation [2004], the Act on Spatial Planning and Development [2003], the Fire Protection Act [1991], the Act on Protection of Agriculture and Forest Land [1995], the act on Geodesy and Cartography Law [1989], Hunting Law Act [1995]; documents like the Environment National Policy [1997], the Forest National Policy [1997], and the Regulation of the Minister of the Environment, Natural Resources and Forestry on detailed rules and procedures for the acknowledgement forests as protective with detailed rules for management of them [1992]. Moreover, some internal regulations of the General Director of the State Forests in aspects related to forest management, including the Instruction for Forest Management [2012], the Principles of Silviculture [2012] and the Instruction for Forest Fire Protection [2012] are equally important. The Instruction for Forest Management is a document, which is updated every 10 years on account of changes of the law and improvement of ways of inventory, taxation and planning. However, in the menatime, some significant changes in the law may also occur. 


\section{SPATIAL DIVISION}

Each forest area has to be divided into a network of compartments by the use of major rides and compartment lines, size of which is dependent on intesivity of management [19]. A forest spatial (area) division is designed in order to improve sense of direction in the field, on maps and in the stand description. Aditionally, it enables maintaining spatial order in a forest working circle. The function of designed major rides and compartment lines is oriented towards protection from winds (protective function), as well as to simplify timber transport [6]. Moreover, it makes stands available for all forest tending activities, enhances fire protection and helps to prevent from gradation of pests. Finally, spatial division is also important in case of the organization of hunts or places for temporary timber storage [19].

A well-designed area division consists of an appropriate direction of major rides and compartment lines, as well as size and shape of compartments (limited by fotest site conditions, landform and intensity of silviculture system).

Compartments are usually in a shape of a rectangle becaue from the design point of view, this shape is the most advantageous for designing and implementing thinnings and cuttings according to selected clearcutting systems within forest parcels. The shape of compartments enables to establish big clearcut areas and to retain the protective function of a neighbouring stand boundary [19]. The way of determining of major rides and compartment lines is meaningful for the forest environment. A natural forest area division is designated by existing natural demarcations, eg. roads, ditches, rivers, streams sts. It is typical for protection or reserve forests, in which the productive function is dominated by nonproductive functions (esthetic, landscape). In case of productive forests, the most popular is a combined forest area division which combines features of natural and artificial systems.

On balance, the significance of spatial division to the forest environment is indubitable, what results from its functions and ways of establishing.

\section{MANAGEMENT PRESCRIPTIONS}

Management prescriptions are included in a stand description, which is a document cointaing results of measurements and description of a site and a subcompartment, including tree and stand features, considered to be necessary to prepare the forest management plan for a forest district for a 10-years period. Basically, they concerns forest utilisation, silviculture, forest protection, as well as other management activities. All prescriptions should concern long and midterm objects of forest management and respond current needs of the forest. A 
forest planner should take into account principles resulting from legal acts, as well as from local conditions [6].

In case of productive forests, the forest planner makes a decision on the type of cutting (felling) method, the size of clearcut area, forest conversion, forest regeneration and others specific aspects related to forest produce (e.g. intermediate treatment).

Management prescriptions for silviculture should concern all areas which require land improvement, afforestration, natural and artificial regeneration, under planting and stand tending within forest cultivation and thickets.

In case of protective forests, on the basis of the Forest Act [1991] management prescriptions have to be adapted to requirements reluting from the forest function according to the category of protection.

Objects of forest protection arise from the state of forest on the day of forest inventory and forecasts from the Forest Protection Enterpise. These objects should be based on the analysis of current and expected threats. A particular attention is payed on areas which are persistently attacked by biotic, abiotic and anthropogenic factors.

Forest management is characterised by a broad spectrum of planned activities, implementation of which is assigned to forest divisions. Decisions made during the implementation of these activities need to be consulted with foresters. Management prescriptions are the final result of inventory and taxation of forest. They are the basis for the future forest management plans and influence on time and spatial order.

\section{TIME ORDER}

Time order means the order of forest utlisation, it covers variours forest functions and rotation of ages of each tree of each tree species, as well as the advancement of natural regeneration providing spatial order.

According to the dominating function of forest, the following silviculture systems are established: special silviculture and protection system (S), multifunctional forest protection system $(\mathrm{O})$, multifunctional forest productive system $(G)$ [19]. An avarage felling age which is the age of a tree, or a stand, in a managed forest at which they reach the management objective, is approved druring the Preliminary Planning Commission (KZP).

While a rotation age of individual stand is established by forest planners and includes: stand composition, forest stand damage degree, compatibility of a stand composition with a stand type [19].

After completing field works, during the Technical and Management Meeting (NTG), an analysis of the compatibility of proposed cutting yield with a target state of timber resources within a forest district, at the end of the economic 
period, is carried out. If the proposed cutting yield do not accord with planned targets it has to be modified, it may concern silviculture systems, cadastral districts or forest districts.

It is believed that cutting trees is an inimical to the forest environment. Hence foresters take into account the fact that for the public, forest is a place for leisure and recreation, rather than for a timber production. On the other hand, the cutting yield included in the forest management plan is the final stage of activities oriented to not only a timber production but also a forest protection. Final decisions have to be made according to the law, and its forecasted results cannot be a threat to a continuous cover forest [Czuba 2005]. The time order is a cause for concern of Miś [2003], Poznański [2004], Magnuski and Jaszczak [2008c], Jaszczak and Magnuski [2012], Jaszczak [2014a, b].

\section{SPATIAL ORDER}

Spatial order enables to take into account natural conditions in forest managemnet, as well as to plan and organise activities connected with management, protection and maintance of forest resources. In a classic approach, it is identified with felling series layout as forest management system; based on the principles of sustainablility, contuinity and regularity of forest utilization.

The basis of establishing of felling series layout is a distribution of uneven-aged stands. Each felling series as a spatial unit, consists of stands that are encompassed with the same direction of cuttings (felling) which is opposite to the direction of wind. Side-walls of stands, within each felling series, take on the role of their own protective elements, mainly windproof. A well-planed spatial order helps to cut stands, at a felling age, wihout damages to neighbouring stands. Thus, spatial order is a natural way of protection from weather conditions (winds, temperature, insolation) and it guarantees an appropriate age structure and stand composition of forests. It provides the relative stability of forest functions $[18,19]$ and affects the forest environment in managed forests.

\section{FOREST MANAGEMENT VS. SPATIAL PLANNING OF REGION}

The latest amendment of the Instruction for Forest Manegement spotlighted a number of specific issues, in particular, the need of taking into consideration resolutions of area development plans and rural development programmes in the process of creating forest management plans. Gathering and compiling information on basic assumptions of the spatial development policy of the region related to forest mangement and nature protection is an important stage 
of forest management planning. They are presented by the District Forest Chief Officer as a report, during the Preliminary Planning Commission, in which generally expected effect of implementation of the spatial development policy of the region and municipalities on sustainable forest management is described. It concerns mainly nature protection, landscape protection and protection of agriculture and forest land [6].

Then, during the Technical and Management Meeting, information form the District Forest Chief Officer's report, and administrative local units (municipalities, districts, voivodeships) which deal with spatial planning, are compared and updated to the new conditions. In case of acceptance of all issues discussed during the NTG, they are included in the general description of a Forest District.

\section{FORECAST OF IMPACT ON ENVIRONMENT AND NATURA 2000 SITES FOR FOREST MANAGEMENT PLAN}

Since 2004, Poland is a full member of the European Union. It brings benefits, but also responsibilities. In case of forest management, it resulted in the need to prepare a strategic assessment of the forest management plan on the environment and the Natura 2000 sites.

Provisions of the six EU directives [the Council Directive on the conservation of natural habitats and of wild fauna and flora (92/43/EWG), the Council Directive on environmental impact assessment (85/337/EWG), the Council Directive on Strategic Environmental Assessment Directive (2001/42/WE), the Council Directive on public access to environmental information (2003/4/WE), the Council Directive providing for public participation in respect of the drawing up of certain plans and programmes relating to the environment (2003/35/WE), the Council Directive concerning integrated pollution prevention and control (2008/1/WE)] are included in the Polish law system through the Act on Access to Information on the Environment and its Protection and on Environmental Impact Assessment [2008].

In the current Instruction for Forest Management [2012] the following specific guidelines on environmental impact assessment of forest management plans on the forest environment and the Natura 2000 sites are mentioned:

- to agree the scope and level of detail of the information required to elaborate a forest management plan and an environmental impact assessment of it on the environment between the the Regional Director of Nature Protection, the National Health Inspector and the Regional Director of the State Forests;

- to elaborate a forecast of environmental impact of forest management plans on the forest environment and the Natura 2000 sites; 
- to get from the Regional Director of Nature Protection and the National Health Inspector opinions on the project of forest management plan and the forecast of environmental impact of it on the environment;

- to provide for public participation in respect of the drawing up of certain plans and programmes relating to the environment.

Among a number of aspects included in the forecast there are for example [6]:

- an analysis with an assessment of the environment state, from the point of view of implementation of the forest management plan;

- the forecast of impact of the implementation of forest management plan on the environment and objectives of protection of the Natura 2000 sites;

- a list of activities and the description of objectives of forest management, both of which are oriented at limiting the negative impact on the environment and the Natura 2000 sites.

Lastly, a map of protected areas and forest functions is attached to each forecast of environmental impact assessment.

Despite existing guidelines, there is a discussion on some ambiguities regarding the primacy of different plans designed for the same area, as well as the competence of authorities and the State Forests in case of the Natura 2000 sites $[3,4,5,24,25,27,28]$.

\section{CONCLUSIONS}

Forest management is the specialization which covers a broad spectrum of planned activities and have a significant impact on the forest economy and the environment, not only in a 10 year period, but also in a long-term time horizon. Decisions made in the process of management of forest areas result from a rich history, an acquired experience of foresters and scientists, as well as current public expectations. A well-planned and well-balanced forest management, which takes into account all functions of forests, enables to maintain the stability of stands, as well as ensure a forest protection for the further generations of people.

\section{REFERENCES}

1. Borecki T.: Znaczenie urzadzania lasu $w$ trwałym $i$ zrównoważonym rozwoju gospodarki leśnej. W: Urządzanie lasu w służbie polskiego leśnictwa. Materiały na Konferencję naukowo-techniczną Rogów, 12-13 kwietnia 2007r. BULiGL, Warszawa, 3-10.

2. Czuba M.: Możliwości pozyskiwania surowca drzewnego $w$ Lasach Państwowych - stan obecny i prognoza na najbliższe lata. Biblioteczka Leśniczego, z. 213. SITLiD, DGLP, Warszawa, 2005, ss. 13. 
3. Dawidziuk J., Zajączkowski S.: Ochrona przyrody $w$ planach urzadzenia lasu w Lasach Państwowych. Zarządzanie Ochroną Przyrody w Lasach 5, 2011, s. 228-244.

4. Dawidziuk J., Zajączkowski S.: Znaczenie urządzania lasu $w$ budowie systemu planistyczno-prognostycznego w leśnictwie. W: Arkuszewska A., Lotz D., Szujecka G. [red.]. Zimowa Szkoła Leśna przy Instytucie Badawczym Leśnictwa. V Sesja. Planowanie w gospodarstwie leśnym XXI wieku. Sękocin Stary, 19-21 marca 2013r. Inst. Bad. Leśn., PGL LP, 32-47.

5. Dawidziuk J., Zajączkowski S.: Miejsce ochrony przyrody $w$ leśnych dokumentach planistycznych. W: Narodowy Program leśny. Panel ekspertów „Ochrona”. Lasy i gospodarka leśna jako narzędzia kształtowania środowiska naturalnego i ochrony przyrody. Sesja 3. Inst. Bad. Leśn. Sękocin Stary. 24 czerwca 2014r., ss. 21.

6. Instrukcja urządzania lasu. Część I. Instrukcja sporządzania projektu planu urządzenia lasu dla nadleśnictwa. 2012. PGL LP, Centrum Informacyjne LP. Warszawa.

7. Jaszczak R.: Urządzanie lasu w Polsce do 1939 roku. Część I - początki urzadzania lasu na ziemiach polskich. Sylwan 152 (3) (2008a) 13-21.

8. Jaszczak R.: Urządzanie lasu w Polsce do 1939 roku. Czesść II - urządzanie lasu w Królestwie Polskim. Sylwan 152 (5) (2008b), 3-13.

9. Jaszczak R.: Urzadzanie lasu w Polsce do 1939 roku. Część III - urzadzanie lasu na ziemiach polskich $w$ zaborze pruskim i austriackim. Sylwan 152 (9) (2008c), 3-10.

10. Jaszczak R.: Urzadzanie lasu w Polsce do 1939 roku. Czesść IV - urzadzanie lasu w latach 1918-1939. Sylwan 152 (10) (2008d), 3-13.

11. Jaszczak R.: Inwentaryzacja zasobów drzewnych $w$ urzadzaniu lasu $w$ Polsce. Sylwan 152 (5) (2008e), 14-25.

12. Jaszczak R.: Podziat lasu na gospodarstwa w Polsce. Sylwan 158 (4) (2014a), 298-305.

13. Jaszczak R.: Rola $i$ znaczenie różnych etatów $w$ regulacji użytkowania rębnego w Polsce. Sylwan 158 (5) (2014b), 390-400.

14. Jaszczak R.: . Urzqdzanie lasu. W: Propedeutyka leśnictwa, Wyd. UP Pozn., Poznań, 2015, 73-85.

15. Jaszczak R., Wajchman S., Taryma B.: Urzadzanie lasu na ziemiach polskich - opis warunków siedliskowych $w$ XIX wieku. Stud. Mater. Ośr. Kult. Leśn., 12 (2013a), 41-50.

16. Jaszczak R., Wajchman S., Taryma B.: Urzadzanie lasu na ziemiach polskich - opis warunków drzewostanowych w XIX wieku. Sylwan 157 (10) (2013b), 793-800.

17. Jaszczak R., Wajchman S., Udziat i rola czynnika społecznego w tworzeniu planów urządzenia lasu w Polsce. Sylwan 158 (3) (2014), 231-240. 
18. Jaszczak R., Magnuski K.:Urządzanie lasu. Poznań, Wyd. UP Pozn., 2012, ss. 492.

19. Kukuła J., Magnuski K., Miś R., Ważyński B., Żółciak E.: Zagadnienia praktyczne $z$ urzadzania lasu. Część I. Inwentaryzacja lasu $i$ plany urzadzenia lasu. Poznań, Wyd. AR Pozn., 1997, ss. 282.

20. Magnuski K., Jaszczak R.: Urzadzanie lasu w Polsce po drugiej wojnie światowej $w$ świetle źródtowych publikacji Sylwana. Część I. Okresy rozwoju urzadzania lasu. Sylwan 152 (6) (2008a), 22-32.

21. Magnuski K., Jaszczak R.: Urzadzanie lasu w Polsce po drugiej wojnie światowej $w$ świetle źródtowych publikacji Sylwana. Część II. Inwentaryzacja lasu. Sylwan 152 (7) (2008b), 9-18

22. Magnuski K., Jaszczak R.: Urzadzanie lasu w Polsce po drugiej wojnie światowej w świetle źródłowych publikacji Sylwana. Część III. Regulacja i planowanie w gospodarstwie leśnym. Sylwan 152 (8) (2008c), 3-16.

23. Miś R.: Urzadzanie lasów wielofunkcyjnych. Poznań, Wyd. AR, 2003, ss. 387.

24. Miotke M.: Prognoza oddziatywania planu urzadzenia lasu na środowisko $i$ obszary Natura 2000 na przykładzie wybranych nadleśnictw RDLP Wrocław i Katowice. Rozpr. dokt. Maszyn. Kat. Urządzania Lasu, 2013, Poznań.

25. Miotke M, Jaszczak R.: Predictions regarding the impact of the forest management plan on environment and Natura 2000 regions in Poland in the context of sustainable development. Journal of Management and Sustainable Development 2 (29) (2011), 127-130.

26. Poznański R.: Nowe metody regulacji w urządzaniu lasu. Kat. Urządzania Lasu AR w Krakowie, 2004, Kraków, ss. 195.

27. Przypaśniak J.: Ocena realizacji prognoz oddziaływania planu urzadzenia lasu na środowisko. W: Arkuszewska A., Lotz D., Szujecka G. [red.]. Zimowa Szkoła Leśna przy Instytucie Badawczym Leśnictwa. V Sesja. Planowanie w gospodarstwie leśnym XXI wieku. Sękocin Stary, 19-21 marca 2013r. Inst. Bad. Leśn., LP, 119-144.

28. Wasiak A.: Wielofunkcyjna gospodarka leśna $w$ planach urzadzenia lasu. W: Arkuszewska A., Lotz D., Szujecka G. [red.]. Zimowa Szkoła Leśna przy Instytucie Badawczym Leśnictwa. V Sesja. Planowanie w gospodarstwie leśnym XXI wieku. Sękocin Stary, 19-21 marca 2013r. Inst. Bad. Leśn., LP, 24-31.

\section{Legal acts}

29. Dyrektywa Rady 85/337/EWG z dnia 27 czerwca 1985r. w sprawie oceny wpływu wywieranego przez niektóre przedsięwzięcia publiczne i prywatne na środowisko. Dz. U. W. E. L. 175/40 z 1985r. 
30. Dyrektywa Rady 92/43/EWG z dnia 21 maja 1992r. w sprawie ochrony siedlisk przyrodniczych oraz dzikiej fauny i flory. Dz. U. W. E. L. 206/7 z 1992r.

31. Dyrektywa Parlamentu Europejskiego i Rady 2001/42/WE z dnia 27 czerwca 2001r. w sprawie wpływu niektórych planów i programów na środowisko. Dz. U. W. E. L. 197/30 z 2001r.

32. Dyrektywa Parlamentu Europejskiego i Rady 2003/4/WE z dnia 28 stycznia 2003r. w sprawie publicznego dostępu do informacji dotyczących środowiska i uchylająca dyrektywę Rady 90/113/EWG. DZ. U. U. E. L. 41/26 z 2003r.

33. Dyrektywa Parlamentu Europejskiego i Rady 2003/35/WE z dnia 26 maja 2003r. przewidująca udział społeczeństwa w odniesieniu do sporządzania niektórych planów i programów w zakresie środowiska oraz zmieniająca $\mathrm{w}$ odniesieniu do udziału społeczeństwa i dostępu do wymiaru sprawiedliwości dyrektywy Rady 85/227/EWG i 96/61/WE. Dz. U. U. E. L. z 2003r.

34. Dyrektywa Parlamentu Europejskiego i Rady 2008/1/WE z dnia 15 stycznia dotycząca zintegrowanego zapobiegania zanieczyszczeniom i ich kontroli. Dz. U. U. E. L. z 2008r.

35. Polityka leśna państwa. MOŚ, ZNiL, Warszawa 1997.

36. www.mos.gov.pl/fileadmin/user_upload/MOS/.../Polityka_leśna_państwa.p df. Dostęp 10.01.2017r.

37. Rozporządzenie Ministra Ochrony Środowiska, Zasobów Naturalnych i Leśnictwa z dnia 25 sierpnia 1992r. w sprawie szczegółowych zasad i trybu uznawania lasów za ochronne oraz szczegółowych zasad prowadzenia w nich gospodarki leśnej. Dz. U. Nr 67, Poz. 337.

38. Rozporządzenie Ministra Środowiska z dnia 26 listopada 2012 r. w sprawie szczegółowych warunków i trybu sporządzania planu urządzenia lasu, uproszczonego planu urządzenia lasu oraz inwentaryzacji stanu lasu ( Dz. U 2012 r., poz.1302).

39. Uchwała Sejmu Rzeczpospolitej Polskiej z dnia 22 maja 2009r. w sprawie przyjęcia dokumentu „Polityka ekologiczna państwa w latach 2009-2012 z perspektywą do roku 2016". MP 2009, nr 34, poz. 501.

40. Ustawa z dnia 17 maja 1989r. Prawo geodezyjne i kartograficzne. Tekst jedn. Dz. U. 2015, poz. 520.

41. Ustawa z dnia 24 sierpnia 1991r. o ochronie przeciwpożarowej. Tekst jedn. Dz. U. 2009, nr 178, poz. 1380.

42. Ustawa z dnia 28 września 1991r. o lasach. Dz. U. 2011, poz. 59; z 2015r., poz. 2100; z 2016r., poz. 422, 586.

43. Ustawa z dnia 3 lutego 1995r. o ochronie gruntów rolnych i leśnych. Tekst jedn. Dz. U. 2015, poz. 909. 
44. Ustawa z dnia 13 października 1995r. Prawo łowieckie. Tekst jedn. Dz. U. 2015, poz. 2168.

45. Ustawa z dnia 27 kwietnia 2001r. Prawo ochrony środowiska. Tekst jedn. Dz. U. 2017, poz. 519.

46. Ustawa $\mathrm{z}$ dnia 27 marca 2003r. o planowaniu i zagospodarowaniu przestrzennym. Tekst jedn. Dz. U. 2016, poz. 778, ze zm.

47. Ustawa z dnia 16 kwietnia 2004r. o ochronie przyrody. Tekst jedn. Dz. U. 2016, poz. 2134, ze zm.

48. Ustawa $\mathrm{z}$ dnia 3 października 2008r. o udostępnianiu informacji o środowisku i jego ochronie, udziale społeczeństwa w ochronie środowiska oraz o ocenach oddziaływania na środowisko. Tekst jedn. Dz. U. 2016, poz. 353, ze zm.

49. Zarządzenie nr 11 dyrektora generalnego Lasów Państwowych z dnia 14 lutego 1995 roku w sprawie prowadzenia gospodarki leśnej na podstawach ekologicznych. ZZ-710-13/95. Dyrekcja Generalna Lasów Państwowych, Warszawa.

50. Zarządzenie nr 11A dyrektora generalnego Lasów Państwowych z dnia 11 maja 1995 roku zmieniające Zarządzenie $\mathrm{nr} 11 \mathrm{w}$ sprawie prowadzenia gospodarki leśnej na podstawach ekologicznych /ZZ-710-13/95/. ZG-71202/99. Dyrekcja Generalna Lasów Państwowych, Warszawa.

\section{URZADZENIOWE ASPEKTY KSZTAETOWANIA ŚRODOWISKA LEŚNEGO}

\section{Streszczenie}

Urządzanie lasu to dyscyplina naukowa mająca za zadanie wypracowanie metod prowadzenia lasu zapewniających realizację zasady trwałego i zrównoważonego rozwoju zasobów leśnych w warunkach leśnictwa wielofunkcyjnego. To dział praktycznego leśnictwa zajmujący się inwentaryzacją i oceną stanu lasu, określeniem zadań hodowlanych i ochronnych oraz sporządzeniem programu ochrony przyrody dla nadleśnictwa, przede wszystkim na najbliższych dziesięć lat, ale także w dłuższym horyzoncie czasowym. Całość zebranych danych wraz z ich analizą stanowi podstawę planu urządzenia lasu.

$\mathrm{W}$ pracy przedstawiono wybrane aspekty urządzania lasu mające istotne znaczenie z punktu widzenia środowiska leśnego.

Słowa kluczowe: podstawy prawne urządzanie lasu, plan urządzenia lasu, zasady i zadania urządzania lasu

Editor received the manuscript: 28.08 .2017 